\title{
6-Alkyl-, 6-aryl- or 6-hetaryl-7-deazapurine ribonucleosides as inhibitors of human or MTB adenosine kinase and potential antimycobacterial agents $\dagger$
}

Cite this: Med. Chem. Commun., 2013, 4, 1497

\author{
Pavla Perlíková, +a Petr Konečný,ł $\dagger^{b}$ Petr Nauš, ${ }^{a}$ Jan Snášel, ${ }^{a}$ Ivan Votruba, ${ }^{a}$ \\ Petr Džubák, ${ }^{b}$ Iva Pichová, ${ }^{a}$ Marián Hajdúch ${ }^{b}$ and Michal Hocek*ac \\ Title 6-alkyl-, 6-aryl- and 6-hetaryl-7-deazapurine ribonucleosides previously known as nanomolar \\ cytostatics were found to be potent inhibitors of either human or mycobacterial (MTB) adenosine kinase \\ (ADK). Several new derivatives bearing bulky substituents at position 6 were non-cytotoxic but \\ selectively inhibited MTB ADK. However, most of the nucleosides (ADK inhibitors) as well as their \\ octadecylphosphate prodrugs were inactive in the whole cell assay of inhibition of Mycobacterium bovis \\ growth. 6-Methyl-7-deazapurine ribonucleoside was found to be a potent antimycobacterial agent.
}

Received 21st August 2013
Accepted 16th September 2013

DOI: $10.1039 / \mathrm{c} 3 \mathrm{md} 00232 \mathrm{~b}$

www.rsc.org/medchemcomm diverse aryl and hetaryl groups at position 6 and systematically studied their activity toward human and MTB ADKs.

\section{Results and discussion}

The synthesis of a series of nineteen 6-alkyl, 6-aryl- and 6-hetaryl-7-deazapurine ribonucleosides $\mathbf{1 b}$-t, nine 7-fluoro derivatives $\mathbf{2 e}, \mathbf{j}-\mathbf{m}, \mathbf{o}-\mathbf{r}$ and six 7-chloro derivatives $\mathbf{3 e}, \mathbf{g}, \mathbf{j}-\mathbf{m}$ has been reported earlier, ${ }^{8}$ as well as the 6-methyl derivative 1a (ref. 12) (Chart 1). Most of these derivatives exhibited strong cytostatic or cytotoxic activities. ${ }^{\mathbf{8 , 1 2}}$

In order to get less cytotoxic derivatives, we have extended the series by synthesis of other six derivatives bearing bulky (het)aryl groups at position 6 (Scheme 1). The dibenzofuryl and benzofuryl derivatives $\mathbf{1} \mathbf{u}$ and $\mathbf{v}$ were prepared by the Suzuki coupling of isopropylidene-protected nucleoside $\mathbf{4}$ followed by deprotection. The other derivatives $\mathbf{1} \mathbf{w}-\mathbf{z}$ were synthesized by direct aqueous Suzuki coupling of 6-chloro-7-deazapurine ribonucleoside with the corresponding hetarylboronic acid in

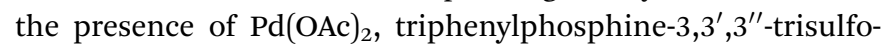
nate (TPPTS) and $\mathrm{Na}_{2} \mathrm{CO}_{3}$. In the case of indole derivative $1 \mathbf{x}$, the coupling was performed with the Boc-protected indole-2boronic acid and the TFA treatment was used for deprotection. In all cases, the products were obtained in good $71-85 \%$ yields.

A synthetic path to 6-(het)aryl-7-deazapurine ribonucleoside5'-octadecylphosphates, as potential lipophilic phosphate prodrugs, was developed starting from isopropylidene-protected ribonucleoside 4. An octadecylphosphate group was attached by reaction with octadecylphosphate in the presence of 2,4,6-trimethylbenzene-1-sulphonyl chloride (MtsCl) in pyridine. Nucleoside-5'-octadecylphosphate 7 was obtained in $58 \%$ yield. Deprotection by treatment with $90 \%$ aqueous TFA provided free 
<smiles>[R]c1ncnc2c1ccn2C1OC(CO)C(O)C1O</smiles><smiles>[R]c1ncnc2c1c(F)cn2[C@@H]1O[C@H](CO)[C@@H](O)[C@H](O)[C@H]1O</smiles><smiles>[R]c1ncnc2[nH]cc(Cl)c12</smiles><smiles>CC1OC(CO)C(O)C(O)C1CO</smiles>
j-m $\mathrm{OH} \mathrm{OH}$<smiles>CC(=O)c1ccccc1</smiles><smiles>COc1ccc(C(C)(C)C)cc1</smiles><smiles>CC(F)(F)c1ccc(F)cc1</smiles><smiles>[CH]1CCC1</smiles><smiles>[BH3-]</smiles>
c d<smiles>CN(c1cccnc1C(C)(C)C(C)(C)c1cccnc1)C(C)(C)C</smiles><smiles>N#Cc1ccoc1</smiles><smiles>CC(C)(C)c1cccs1</smiles>

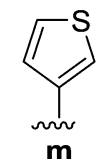
g<smiles>CC(=O)c1cc[nH]c1</smiles><smiles>ClC(=Nc1nccs1)c1ccccc1</smiles><smiles>CC(C)(C)c1c[nH]cn1</smiles><smiles>CC(C)c1ccn[nH]1</smiles><smiles>NN</smiles>

n

Chart 1 Structures of previously known nucleosides $\mathbf{1 a - t}$

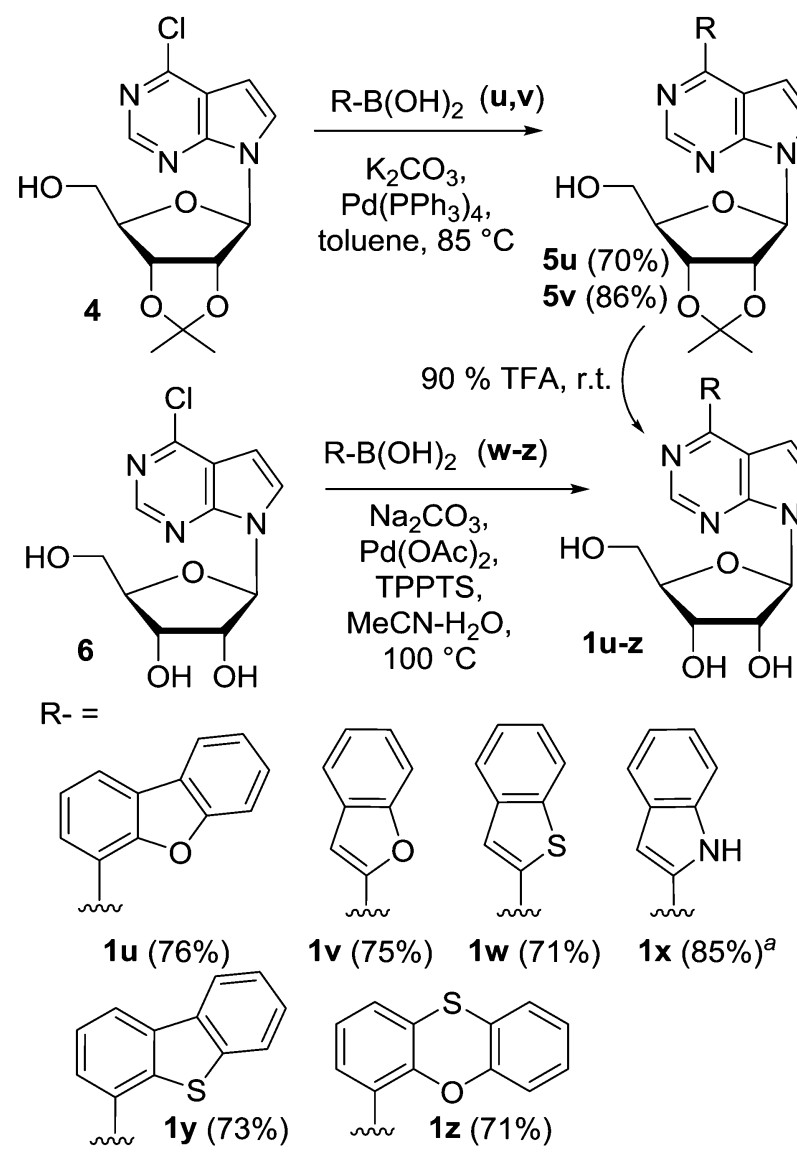

Scheme 1 Synthesis of nucleosides $\mathbf{1} \mathbf{u}-\mathbf{z} .{ }^{a} \mathrm{~N}$-Boc-protected indole-2-boronic acid was used and the Boc was cleaved off by $90 \%$ TFA at rt; the yield is given over two steps. nucleoside-5'-octadecylphosphate 8 (94\%), which was used as a starting material for a series of Stille and Suzuki cross-coupling reactions. Stille cross-coupling reactions with hetaryltributylstannanes were performed in the presence of $\mathrm{PdCl}_{2}\left(\mathrm{PPh}_{3}\right)_{2}$ in DMF at $105{ }^{\circ} \mathrm{C}$. As $5^{\prime}$-octadecylphosphate 8 is insoluble in toluene, standard conditions for the Suzuki cross-coupling reaction had to be slightly modified. The reactions with (het) arylboronic acids were performed in the presence of potassium carbonate and $\mathrm{Pd}\left(\mathrm{PPh}_{3}\right)_{4}$ in $\mathrm{DMF} /$ water $(8: 1)$ at $105^{\circ} \mathrm{C} .6-(\mathrm{Het})$ aryl-7-deazapurine ribonucleoside-5'-octadecylphosphates $\mathbf{9 e}$, $\mathbf{j}-\mathbf{m}$ and $\mathbf{v}$ were obtained in $62-85 \%$ yields (Scheme 2).

All the title nucleosides $\mathbf{1 a}-\mathbf{z}, \mathbf{2 e}, \mathbf{j}-\mathbf{m}, \mathbf{o}-\mathbf{r}, \mathbf{3 e}, \mathbf{g}, \mathbf{j}-\mathbf{m}$ and nucleotides $\mathbf{9 e}, \mathbf{j}-\mathbf{m}, \mathbf{v}$ were tested for the inhibition of human and MTB ADKs (for cloning expression and purification of these enzymes, see ref. 9) and most of them also for substrate activity to the kinases, i.e. for phosphorylation. The results were correlated with their in vitro cytotoxicity (MTT) against nonmalignant BJ and MRC-5 human fibroblast cell lines. The cytotoxicity strongly depended on the bulkiness of the substituent at position 6 . Most active were derivatives bearing fivemembered heterocycles, whereas derivatives bearing bulky aryl groups were generally not cytotoxic, which was consistent with previously published ${ }^{8}$ cytostatic and cytotoxic activities on leukemia and solid tumor cell lines. Most of the nucleosides did not show significant inhibition to human ADK with the exception of bulky derivatives $\mathbf{1} \mathbf{u}-\mathbf{z}$, which showed inhibition with micromolar $\mathrm{IC}_{50}$ values. On the other hand, most of the nucleosides were moderate to good substrates for the human ADK and were readily phosphorylated to nucleoside $5^{\prime}-O$ monophosphates, which is a necessary step in their activation for eventual inhibition of RNA synthesis in their cytostatic or cytotoxic effect. ${ }^{8}$ On the other hand, none of the compounds was found to be a substrate for MTB ADK and most compounds efficiently inhibited this enzyme. While the alkyl-substituted derivatives 1a-d were weak inhibitors of MTB ADK, all the aryl-

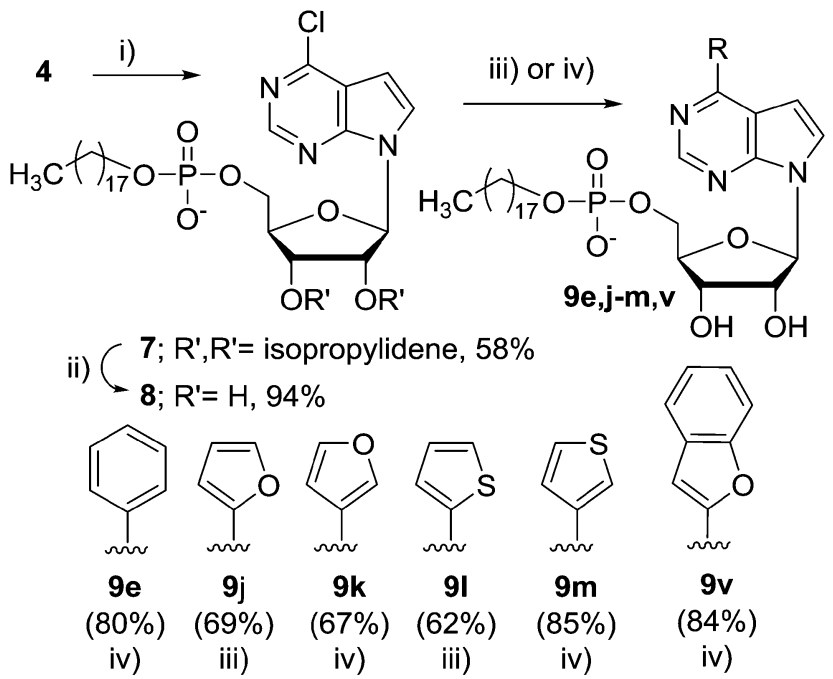

Scheme 2 Reagents and conditions: (i) $\mathrm{C}_{18} \mathrm{H}_{37} \mathrm{OP}(\mathrm{O})(\mathrm{OH})_{2}$ (1.5 equiv), $\mathrm{Mts} \mathrm{Cl}$ (6 equiv), pyridine, rt; (ii) $90 \% \mathrm{TFA}$, rt; (iii) $\mathrm{R}-\mathrm{SnBu}_{3}$ (1.5 equiv), $\mathrm{PdCl}_{2}\left(\mathrm{PPh}_{3}\right)_{2}$ (0.05 equiv)/DMF, $105^{\circ} \mathrm{C}$; (iv) $\mathrm{R}-\mathrm{B}(\mathrm{OH})_{2}$ (1.5 equiv), $\mathrm{K}_{2} \mathrm{CO}_{3}$ (2 equiv), $\mathrm{Pd}\left(\mathrm{PPh}_{3}\right)_{4}$ (0.05 equiv), $\mathrm{DMF} / \mathrm{H}_{2} \mathrm{O}(8: 1), 105^{\circ} \mathrm{C}$. 
Table 1 Cytotoxicity, human and MTB ADK inhibition and antimycobacterial activity

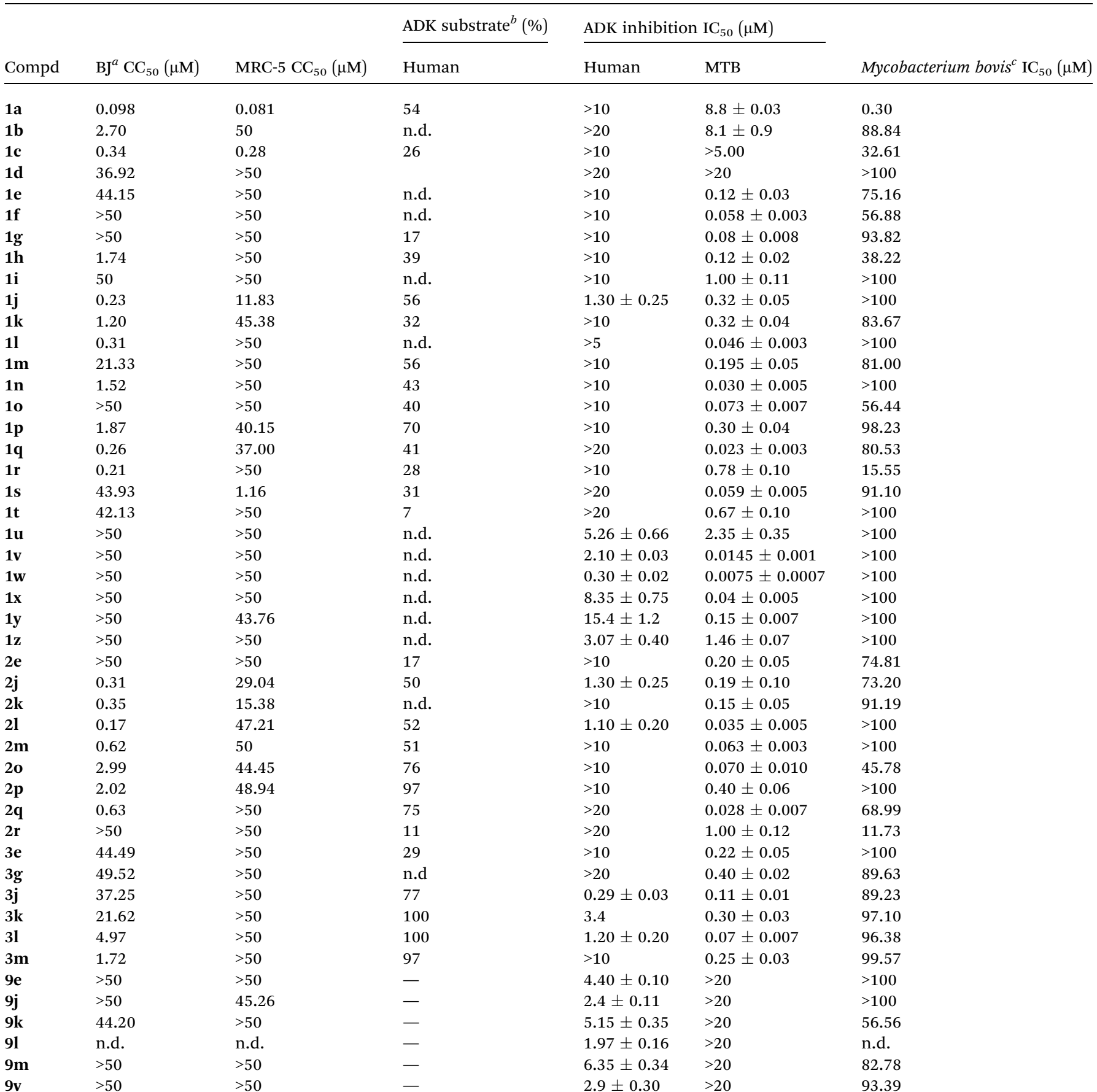

${ }^{a}$ Cytotoxicity (MTT test) in BJ and MRC-5 fibroblasts. ${ }^{b}$ ADK substrate activity, conversion to $5^{\prime}$-phosphate (\%). ${ }^{c} 50 \%$ growth inhibitory concentration of in vitro cultivated Mycobacterium bovis BCG.

and hetaryl-substituted 7-deazapurine ribonucleosides (1e-z), including 7-fluoro- (2) and 7-chloro-derivatives (3) were strong inhibitors of this enzyme with submicromolar to low nanomolar IC $_{50}$ values. Most of the derivatives bearing phenyl and five-membered hetaryl groups at position 6 (1e-i, $\mathbf{k - t}, \mathbf{2 e}, \mathbf{k}, \mathbf{m}-\mathbf{r}$ and $3 \mathbf{e}, \mathbf{g}, \mathbf{m}$ ) were selective inhibitors of the MTB ADK and did not significantly inhibit the human enzyme (but were strongly cytotoxic). 6-Furyl derivatives $\mathbf{1} \mathbf{j}$ and $\mathbf{2} \mathbf{j}$ and the thienyl derivative
21 were less selective, inhibited both enzymes and were cytotoxic. The derivatives bearing bulky aryl groups $\mathbf{1 u}-\mathbf{z}$ inhibited the MTB ADK in low nanomolar concentrations while the inhibition of human enzyme was observed at micromolar concentrations, and so the selectivity index was 2-3 orders of magnitude. These bulky derivatives were not cytotoxic. The octadecylphosphate prodrugs 9 were moderate inhibitors of the human ADK and inactive against MTB enzyme. 
All the derivatives were also tested for in vivo inhibition of Mycobacterium bovis growth (Table 1). From all tested nucleosides only compound 1a displayed very significant antimycobacterial activity $\left(\mathrm{IC}_{50}=0.3 \mu \mathrm{M}\right)$ but showed the highest cytotoxicity. This derivative, however, only weakly inhibited in vitro $\mathrm{MTB} \mathrm{ADK}\left(\mathrm{IC}_{50}=8.8 \mu \mathrm{M}\right)$ which may indicate that the mode of antimycobacterial activity of this compound is independent of MTB ADK and rather suggests a more general cytotoxic mechanism. Two 6-(imidazolyl)deazapurine nucleosides 1r and $2 \mathbf{r}$ exerted moderate antimycobacterial activity $\left(\mathrm{IC}_{50}=\right.$ 15.6 and $11.7 \mu \mathrm{M}$, respectively) accompanied by preferential inhibition of MTB ADK and low cytotoxicity, whereas all other nucleosides were virtually inactive. The octadecylphosphate prodrugs 9e, j-m and $\mathbf{v}$, which were designed as lipophilic derivatives with increased penetration through the mycobacterial cell wall, did not show any antimycobacterial activity either.

\section{Conclusions}

It can be concluded that the 6-(het)aryl-7-deazapurine ribonucleosides are strong and mostly selective inhibitors of MTB ADK but not the human ADK. Nonetheless, they showed only limited potential to inhibit growth of mycobacteria. One reason could be their poor penetration through the mycobacterial cell wall. Alternatively, the mycobacterial ADK may not be a suitable target for therapy since AMP also can be biosynthesized by the salvage pathway from adenine utilizing adenine phosphoribosyl transferase or by a reaction sequence from IMP. ${ }^{5}$

\section{Acknowledgements}

This work was supported by the institutional support from the Academy of Sciences of the Czech Republic (RVO: 61388963), a grant of the Czech Science Foundation (P207/11/0344), EU-PF7 SysteMtb Collaborative Project no. 241587, and by Gilead Sciences, Inc. Infrastructural part of this project (Institute of Molecular and Translational Medicine) was supported by the Operational Programme Research and Development for Innovations (project CZ.1.05/2.1.00/01.0030). We thank Mrs Dagmar Grundová for excellent technical assistance.

\section{Notes and references}

1 Reviews: (a) E. De Clercq, J. Med. Chem., 2010, 53, 1438-1450; (b) E. De Clercq, Nucleosides, Nucleotides Nucleic Acids, 2012, 31, 339-352.

2 Reviews: (a) W. B. Parker, J. A. Secrist, III and W. R. Waud, Curr. Opin. Invest. Drugs, 2004, 5, 592-596; (b) C. M. Galmarini, F. Popowycz and B. Joseph, Curr. Med. Chem., 2008, 15, 10721082; (c) W. B. Parker, Chem. Rev., 2009, 109, 2880-2893.

3 Examples: (a) A. Scozzafava, A. Mastrolorenzo and C. T. Supuran, Bioorg. Med. Chem. Lett., 2001, 11, 1675-
1678; (b) A. K. Pathak, V. Pathak, L. E. Seitz, W. J. Suling and R. C. Reynolds, J. Med. Chem., 2004, 47, 273-276; (c) L.-L. Gundersen, J. Nissen-Meyer and B. Spilsberg, J. Med. Chem., 2002, 45, 1383-1386; (d) A. K. Bakkestuen, L.-L. Gundersen and B. T. Utenova, J. Med. Chem., 2005, 48, 2710-2723; (e) M. Braendvang and L.-L. Gundersen, Bioorg. Med. Chem., 2005, 13, 6360-6373.

4 Reviews: (a) M. C. Long and W. B. Parker, Biochem. Pharmacol., 2006, 71, 1671-1682; (b) M. C. Long, S. C. Shaddix, O. Moukha-Chafiq, J. A. Maddry, L. Nagy and W. B. Parker, Biochem. Pharmacol., 2008, 75, 15881600.

5 Reviews: (a) W. B. Parker and M. C. Long, Curr. Pharm. Des., 2007, 13, 599-608; (b) R. G. Ducati, A. Breda, A. Basso, L. A. Basso and D. S. Santos, Curr. Med. Chem., 2011, 18, 1258-1275.

6 M. C. M. Reddy, S. K. Palaninathan, N. D. Shetty, J. L. Owen, M. D. Watson and J. C. Sacchettini, J. Biol. Chem., 2007, 282, 27334-27342.

7 S. W. Muchmore, R. A. Smith, A. O. Stewart, M. D. Cowart, A. Gomtsyan, M. A. Matulenko, H. Yu, J. M. Severin, S. S. Bhagwat, C.-H. Lee, E. A. Kowaluk, M. F. Jarvis and C. L. Jakob, J. Med. Chem., 2006, 49, 6726-6731.

8 P. Nauš, R. Pohl, I. Votruba, P. Džubák, M. Hajdúch, R. Ameral, G. Birkus, T. Wang, A. S. Ray, R. Mackman, T. Cihlar and M. Hocek, J. Med. Chem., 2010, 53, 460470.

9 P. Spáčilová, P. Nauš, R. Pohl, I. Votruba, J. Snášel, H. Zábranská, I. Pichová, R. Ameral, G. Birkuš, T. Cihlár and M. Hocek, ChemMedChem, 2010, 5, 1386-1396.

10 P. Perlíková, R. Pohl, I. Votruba, R. Shih, G. Birkuš, T. Cihlár and M. Hocek, Bioorg. Med. Chem., 2011, 19, 229-242.

11 Examples: (a) B. G. Ugarkar, J. M. DaRe, J. J. Kopcho, C. E. Browne, III, J. M. Schanzer, J. B. Wiesner and M. D. Erion, J. Med. Chem., 2000, 43, 2883-2893; (b) B. G. Ugarkar, A. Castellino, J. M. DaRe, J. J. Kopcho, J. B. Wiesner, J. M. Schanzer and M. D. Erion, J. Med. Chem., 2000, 43, 2894-2905; (c) B. G. Ugarkar, A. J. Castellino, J. S. DaRe, M. Ramirez-Weinhouse, J. J. Kopcho, S. Rosengren and M. D. Erion, J. Med. Chem., 2003, 46, 4750-4760; (d) B. C. Bookser, M. C. Matelich, K. Ollis and B. G. Ugarkar, J. Med. Chem., 2005, 48, 33893399; (e) S. H. Boyer, B. G. Ugarkar, J. Solbach, J. J. Kopcho, M. C. Matelich, K. Ollis, J. E. Gomez-Galeno, R. Mendonca, M. Tsuchiya, A. Nagahisa, M. Nakane, J. B. Wiesner and M. D. Erion, J. Med. Chem., 2005, 48, 6430-6441; (f) Y. A. Kim, A. Sharon, C. K. Chu, R. H. Rais, O. N. Al Safarjalani, F. N. M. Naguib and M. H. el Kouni, J. Med. Chem., 2008, 51, 3934-3945.

12 R. Wu, E. D. Smidansky, H. S. Oh, R. Takhampunya, R. Padmanabhan, C. E. Cameron and B. R. Peterson, J. Med. Chem., 2010, 53, 7958-7966. 